\title{
AIDS becomes a notifiable disease in Japan despite protests
}

Tokyo

JAPAN is about to introduce legislation to make AIDS (acquired immune deficiency syndrome) a notifiable disease. But critics claim that the law will be a grave infringement of human rights.

The following are the main provisions of the AIDS bill: doctors must report the age, sex and source of infection of AIDSvirus carriers to the prefectural government concerned within 7 days; if a doctor judges that a patient may ignore his instructions, the doctor should immediately report the name and address of the patient to prefectural authorities; the prefectural governors are authorized to recommend or order AIDS tests and medical checkups for people infected or suspected of being infected with AIDS, and a maximum fine of Y 100,000 will be imposed on those who refuse; doctors and public servants who fail to keep the secrets of patients will be subject to maximum imprisonment of up to one year or a fine of less than Y300,000; foreigners infected with AIDS will not be allowed into Japan, for the time being.

Health and Welfare Ministry officials responsible for drawing up the law have found themselves pulled in two directions. On the one hand, some of their scientific advisers, who are involved in the treatment of haemophiliac AIDS patients, wish to guard the privacy of patients; on the other, government officials and politicians are pressing for draconian measures to halt the spread of the disease.

Until very recently, most Japanese regarded AIDS as a disease confined to foreigners and a few Japanese homosexuals and haemophiliacs. But the death

\section{AIDS education programme in Japan Tokyo}

JAPAN is taking several steps to combat AIDS (acquired immune deficiency syndrome). The Health and Welfare Ministry has distributed a 100-page booklet on the disease to prefectural governments across the country; the Education Ministry has instructed education boards to initiate AIDS education from the primary school level up; and television coverage on the disease is now extensive. AIDS-related stocks have soared on the Tokyo stock exchange.

Now Tatsuo Ozawa, a former Health and Welfare Minister who led a mission to the United States last week to study AIDS, has proposed the formation of a private foundation to produce education films and video tapes and to maintain a free phonecounselling service. of a female prostitute in Kobe in January and revelations in the press about a female AIDS-carrier in Kochi have sent government officials rushing to draft anti-AIDS legislation.

According to press reports, the woman in Kochi ignored her doctor's advice, became pregnant without informing her husband that she was an AIDS carrier, and insisted on giving birth even though there is a high risk the child has been infected. (The birth was announced on Monday, but blood tests of the infant will take several weeks.)

In an early draft of the law, those infected with AIDS who engage in 'dangerous acts' (giving blood or having sexual relations) in the full knowledge that they are infected would have been subject to a maximum fine of $\mathrm{Y} 300,000(\$ 2,000)$ or imprisonment for up to one year. And doctors who failed to report AIDS carriers to prefectural authorities would be subject to similar punishment. But protests that these provisions constitute an infringement of human rights led the ministry to drop these clauses from the final draft.

Hoei Ohama, chairman of the recently formed subcommittee on AIDS, of the ruling Liberal Democratic Party (LDP), told reporters that "it is more important to prevent the spread of AIDS than to protect the privacy of high-risk groups" and went on to add that "if we respect the human rights of one person, we are depriving 99 others of the right to live"

Some Justice Ministry officials have even suggested that people infected with AIDS who knowingly pass on the virus to others should face injury or murder charges under existing criminal law.

The Health and Welfare Ministry says the new law will protect the privacy of AIDS sufferers as long as they follow doctors' advice. But what is not made clear is how those secondarily infected with AIDS will be tracked down while preserving that privacy. The clause banning the entry of foreigners is also extremely vaguely worded and there is no description of how it will be enforced

The National Association of Haemophiliacs has condemned the legislation as "inhumane". But if some members of the LDP have their way the law will be strengthened during Diet debate. Tatsuo Ozawa, leader of an AIDS study delegation to the United States, announced in Washington on Friday that he will recommend compulsory medical checks for those employed in massage parlours, and strengthening of the enforcement of AIDS preventative measures while developing measures to protect human rights.

David Swinbanks

\section{Tests for AIDS in pregnancy on offer to all}

\section{Munich}

VOLUNTARY testing for AIDS (acquired immune deficiency syndrome) should be available for all pregnant women. That was the conclusion of an international symposium on infectious diseases in gynaecology and obstetrics held at the University of Munich earlier in the month. The bread-and-butter of the conference, which brought together more than 500 gynaecologists from nine countries, were topics such as toxic-shock syndrome and premature delivery.

A pilot programme of AIDS testing among expectant mothers has already begun in the university hospitals of Munich. According to Ernst Weissenbacher, the organizer of the conference and professor of medicine at the university, "almost nobody" has refused to be tested.

Of the estimated 100,000 carriers of the AIDS virus (HIV) in West Germany, between one and seven per cent are thought to be women. Virtually all carriers of the infection are members of high-risk groups. At present, the results of AIDS tests are confidential between patients and their physicians which, according to Weissenbacher, helps to explain why pregnant women are ready to volunteer for tests. But Bavarian physicians may soon be required to report carriers of the AIDS infection to local health authorities in which case, says Weissenbacher, the situation could change.

The government of Bavaria has put forward one of the most far-reaching programmes of AIDS testing yet proposed. Under intended legislation, tests would be mandatory for applicants for public service jobs as well as those "in danger of infecting others", including members of high-risk groups such as prostitutes and intravenous drug users and their associates.

Under the planned law, those found to be carriers of the infection would be required to inform their physicians and their sexual partners of their condition. The Bavarian government's plans are vigourously opposed by the Minister of Health in the federal government, Rita Süssmuth.

Steven Dickman

\section{New director at BGS}

\section{London}

The UK Natural Environment Research Council (NERC) has appointed Mr F.G. Larminie to a two-year term as director of the British Geological Survey from September, on the retirement of the present director Mr G.I. Lumsden. 